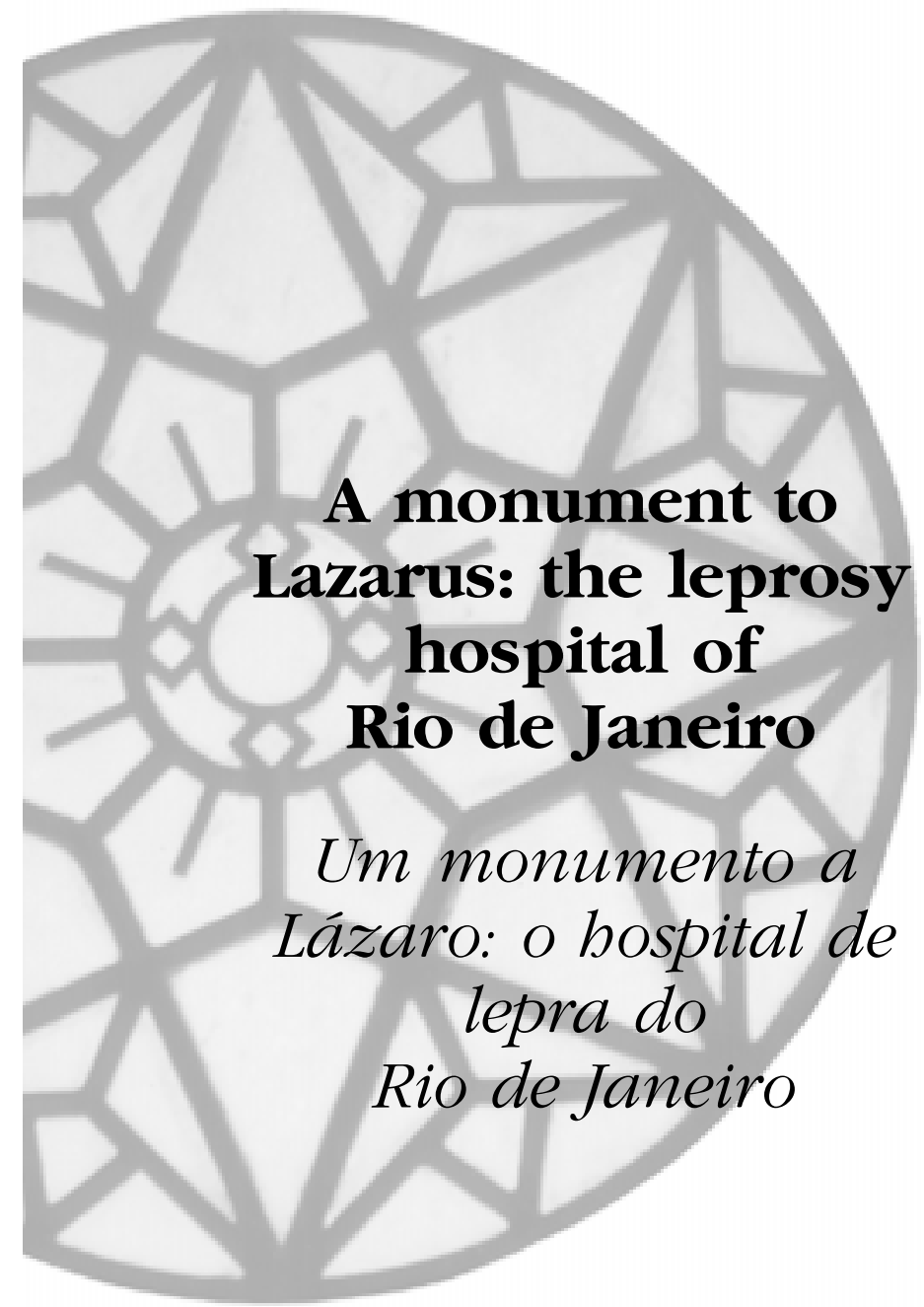

SMITH III, T. H.: 'A monument to Lazarus: the leprosy hospital of Rio de Janeiro'.

História, Ciências, Saúde-Manguinhos, vol. 10 (supplement 1): 143-60 2003.

Soon after the Portuguese made landfall in 1500, Europeans and, later, African slaves introduced leprosy, and Saint Lazarus, the patron saint of its victims, into Brazil. Social and political pressure mounted by the middle of the eighteenth century in the city of Rio de Janeiro to remove those unfortunates from the city's streets even before the move of Brazil's capital in 1763. Frei Antônio, the bishop of Rio, founded the venerable hospital that year in the neighborhood of São Cristóvão. He requested that the Irmandade do Santíssimo Sacramento da Candelária provide oversight and administration. The brotherhood continues to honor its covenant of 239 years ago. The history of this hospital provides insight into the complex relationships that existed between the citizenry and church and state. Rio's leprosy hospital, now the Hospital Frei Antônio, had an important role in the evolution of the health care professions, progress in medical science, and the genesis of the hygienic movement in Brazil. This study also contributes to the history of a disease that persists in 2002 Brazil as a public health issue.

KEYWORDS: leprosy, Hospital Frei Antônio, leprosy hospital, hygienic movement, history of medicine, public health.

SMITH III, T. H.: 'Um monumento a Lázaro: o hospital de lepra do Rio de Janeiro.' História, Ciências, Saúde-Manguinhos, vol. 10 (suplemento 1): 143-60 2003.

Logo após a chegada dos portugueses, em 1500 , os europeus e, mais tarde, os escravos africanos introduziram a lepra no Brasil e, com ela, São Lázaro, o patrono de suas vítimas. No Rio de Janeiro, cresceram as pressões para que as vítimas fossem removidas das ruas da cidade, antes mesmo da mudança da capital do Brasil, em 1763. Neste ano, Frei Antônio, o bispo do Rio de Janeiro, fundou o venerável hospital no bairro de São Cristóvão. Solicitou que a Irmandade do Santíssimo Sacramento da Candelária cuidasse da assistência e administração do hospital. A irmandade continua a honrar o acordo feito há 239 anos. A história desse hospital é uma fonte de conhecimento sobre as relaçôes complexas existentes entre os cidadãos, a Igreja e o Estado. O hospital atualmente chamado Frei Antônio teve importante papel na evolucão de profissões ligadas à saúde, no progresso das ciências médicas e na gênese do movimento higienista no Brasil. Esse estudo também contribui para a bistória de uma doença que persiste no Brasil de 2003 como questão sanitária.

Thomas Hunter Smith III

Adjunct instructor, University College of Medicine Tulane University

New Orleans, Louisiana

THS3rd@aol.com

PALAVRAS-CHAVE: lepra, Hospital Frei Antônio, hospital de lepra, movimento bigienista, história da medicina, saúde pública. 
$\mathrm{T}$ he earliest representatives of Portugal, Spain, France, Holland, and, later, slaves from Africa introduced leprosy and Saint Lazarus, the patron saint of its victims, into Brazil (Scott, 1943, pp. 181-2; Sigerist, 1941, p. 352; Souza Araújo, 1946a, pp. 9-15). The biblical stigma arrived intact with the disease and by the middle of the eighteenth century those so afflicted in Rio de Janeiro suffered significant persecution. Social and political pressure steadily mounted to remove and keep those unfortunates from the city's streets. This study, the history of the Leprosy Hospital of Rio de Janeiro, recounts a part of that saga and attempts to summarize the 239-year history of that magnificent institution, now the Hospital Frei Antônio. It is a "monument to Lazarus" as well as a monument to human compassion; a monument to the commitment of a few to the greater good of Brazilian society.

Isolation of these patients in Brazil began in 1640, near the city of Salvador, Bahia, with the opening of the legendary Campo dos Lázaros, funded by charity. By the end of that century the people of Rio de Janeiro had become greatly alarmed by the increasing number of victims of the disease found in crowded areas of the city and insisted on a solution (Terra, 1919, pp. 41-4). Officials in Rio made an effort in 1697 to found a facility similar to the one in Salvador with the intention of having it annexed to the Church of the Immaculate Conception. That attempt failed. The incidence of the disease continued to escalate in Rio, but shifting political priorities and a lack of funding frustrated other initiatives well into the eighteenth century (Souza Araújo, 1946a, pp. 18-9).

With a population of approximately 20,000 in 1739 , Rio had between three hundred and four hundred victims of leprosy. ${ }^{1}$ Because of the number of patients involved and the accompanying stigma and fear of the disease, by 1739, the people of Rio de Janeiro clearly defined leprosy as a public health threat (Souza Araújo, 1946a, pp. 9-15). Their concern translated into fierce political pressure, but circumstances limited the options available to city leaders.

Their choices certainly included authoritarian measures toward those with the disease. Nonetheless, along with the recognition of the realities of local politics, the issues of civil liberty and human rights did seem to enter into the decision-making process. As an added pressure, those community leaders had to live and govern in Rio de Janeiro, while all major arbitration required approval from Portugal, a slow and capricious process. ${ }^{2}$

Officials appeared to work within the tradition of law inherited from the Iberian Peninsula and to use legally qualified medical consultants to reach rational conclusions. That was reflected in a Municipal Council meeting in Rio on January 21, 1739, in which the city's physicians were assembled to respond to the perceived threat to the public's health (Ribeiro, 1971, pp. 29-30). On May 22, 1740, 
all accessible physicians were assembled in Rio to debate the matter further. They concluded pessimistically that leprosy existed in dangerously significant numbers, that it had a contagious nature, and that it represented a significant danger (Sales, 1971, p. 115). By letter the following day, the municipal council of Rio de Janeiro appealed directly to King John V of Portugal for assistance in establishing a leprosy hospital. ${ }^{3}$

Impressed with the demands that had arrived from Brazil, the king consulted with the Overseas Council on February 1, 1741. Then on February 3, 1741, the king sent a carta régia (royal directive) directing Gomes Freire de Andrade, Governor and Captain General of the Captaincy of Rio de Janeiro, to do and spend whatever he needed to establish a leprosy hospital with an appropriate and effective administration. ${ }^{4}$ On August 7, 1741, Gomes Freire sent a humble and understated letter to Viceroy André de Mello e Castro, in Bahia, that he had been given the opportunity to establish a lazareto and that he had, in spite of his own tardiness, accomplished that (Souza Araújo, 1946a, p. 37). In fact, with no government funds available and at his own expense, Gomes Freire de Andrade had a rudimentary facility constructed. That consisted of a few simple cottages in the neighborhood of São Cristóvão at the foot of the hill on which the hospital remains in the year 2002 (Pinheiro, 1893, p. 14).

By the time the capital of Brazil was moved from Salvador to Rio in 1763, leprosy had spread through the provinces of Maranhão, Pernambuco, Bahia, Espírito Santo, São Paulo, and Rio de Janeiro (Ribeiro, 1971, p. 29), and had appeared in Minas Gerais, Mato Grosso, and probably in Pará (Souza Araújo, 1946a, pp. 108, 133-4). With the move of the capital to Rio in 1763 , the Portuguese affirmed the growing political and economic importance of southern Brazil and within the new capital, officials and dignitaries were expected to actually solve some problems that had previously received little more than flamboyant rhetoric or treatment of a provisional nature. The city's casualties of leprosy had fallen into the overlapping spheres of incipient politics and an ill-defined system of public health. This began to change as Rio de Janeiro entered the 'time of the viceroys'.

\section{Time of the viceroys}

With the death of Governor Gomes Freire de Andrade on January 1, 1763, Bishop Frei Antônio do Desterro of the Benedictine Order became one of a triumvirate that governed temporarily in Rio until the king could place a viceroy there. ${ }^{5}$ On February 11, 1763, as an apparent exercise of his newfound power, Frei Antônio requested that the Irmandade do Santíssimo Sacramento da Freguesia de Nossa Senhora da Candelária (Brotherhood of the Most Holy Sacrament of 
the Parish of Our Lady of Candelária, henceforth referred to as the Irmandade), assume the administration of the leprosy asylum (Pinheiro, 1893, p. 18). ${ }^{6}$ Two days later the Irmandade met and accepted that covenant by a unanimous vote of the fifteen members present. On February 15, 1763, the provedor (head of or purveyor) of the Irmandade, Captain Antônio d'Oliveira Durão, accompanied by the treasurer, secretary, and procurador (an agent or attorney), delivered a copy of the formal terms of acceptance and a plan of organization to the bishop, Frei Antônio (Pinheiro, 1930, vol. 2, p. 361).

The Irmandade took possession of the relatively primitive facility erected in 1741. It housed 52 patients, four male nurses, and as servants several females of African descent convicted of serious crimes and delivered straight from jail (Souza Araújo, 1946a, p. 54). During the ensuing years the institution survived by charitable contributions, but the government inevitably involved itself again in the leprosy problem in the person of viceroy Count da Cunha. ${ }^{7}$

Obviously well after Frei Antônio's initiation of plans for the hospital on February 11, Count da Cunha did not assume responsibilities as Brazil's tenth viceroy until October 19, 1763 (Souza Araújo, 1946a, p. 54). Although the viceroy did not found the Leprosy Hospital, he soon took an official interest. Aware of the ravages of the disease, endemic in Angola and Bahia, the first viceroy in the new capital of Rio sought to improve the victims' plight by focusing on preventive measures.

On December 19, 1763, the viceroy wrote a long and detailed letter to Francisco Xavier de Mendonça Furtado, Secretary of State for the overseas dominions and brother of the Portuguese dictator (Sebastião José de Carvalho e Melo) who later became the Marquis of Pombal. ${ }^{8}$ The viceroy emphasized that the leprosy problem in Rio had his full attention and that he had visited the existing facility and found conditions there unacceptable. The letter further related that people with the disease appeared in plazas throughout the city and that they had infected the water supply by bathing in every stream. He stressed that the Irmandade did not have the resources to sustain a proper hospital, and that the existing facility had places for only 52 patients, leaving another 350 of both sexes and all classes on the outside without care. From the very first perception of a public health threat from this disease in Rio, its victims and their fate entered the domain of both religion and politics, as it has in most of the Judeo-Christian world.

As a permanent leprosy hospital, the viceroy recommended adapting the confiscated Jesuit property in the parish of São Cristóvão, by then a patrimony of the crown, located near the existing facility. Confiscation of Jesuit wealth in 1759 did not yield the expected riches for the crown (Alden, 1959, p. 522), but the property seized at São Cristóvão and the Fazenda (plantation) de Santa Cruz and its 
beef would prove to be pivotal in the early survival of the hospital. The Jesuits had built a monastery at São Cristóvão for rest and recreation in 1752 . The viceroy emphasized that it produced no revenue, remained uninhabited, and had begun to fall into a state of disrepair. The viceroy posited that the building had the capacity for one hundred patients, with enough space to separate men and women. Da Cunha acknowledged that a hospital in the Jesuit monastery could not accommodate all of those with the disease, but asserted that additional rooms could be added without great difficulty or undue expense. The structure also had a chapel at its center, and was near the river Maracanã, which had potable water.

The viceroy continued with a reminder that royal resolutions in 1760 and 1761 had pledged to build a hospital at an appropriate place in Rio. He further proposed the use of funds already approved in the above resolutions, owed to the city by the Companhia dos Vinhos do Alto Douro (Wine Company of the Alto Douro), in payment for its monopoly rights to sell wine (Maxwell, 1995, p. 62). ${ }^{9}$ The viceroy then expressed concern about having the resources for the hospital's daily operation, even if the king permitted the annual collection of a modest progressive contribution from the households of Rio encompassing commoners through the nobility. He argued that the people of the city would not object to a small financial sacrifice to rid the streets of the diseased. Da Cunha closed that memorable letter with a recommendation to leave the operation of the hospital in the hands of the Irmandade. ${ }^{10}$

The viceroy received a reply from Mendoça Furtado in the form of an Aviso Régio, in other words with the king's sanction, dated January $31,1765 .{ }^{11}$ In it the king agreed with every recommendation, from the use of the former Jesuit property at São Cristóvão to the financial resources needed to meet the hospital's expenses. ${ }^{12}$ Finally, those with leprosy had a new home, and the people of Rio de Janeiro had a new tax.

The earliest statutes governing the hospital are no longer in existence, but the 22 statutes issued by the viceroy in 1766 do exist, but may only be generalized in this venue. Those legal instruments specified very strict parameters for the acceptance and discharge of a patient and dealt extensively with administration of the institution, its professional and supporting staff including priests, rules of patient care, the moral conduct of all concerned, and, of course, finances. ${ }^{13}$

Statute four attacked the freedom of those with leprosy and affirmed the intention of incarcerating all with the disease regardless of social status or financial condition and authorized force if necessary. The sixth statute was designed to avoid hospitalizing a person with an incorrect diagnosis. It required that each patient appear before a committee composed of a presiding minister, the physician and surgeon of the hospital, an outside physician, and a representative 
of the High Court of Appeals. For admission, the patient then had to have an order written by the hospital physician and cosigned by the presiding minister. In the unlikely event of a patient's discharge, the entire process worked in reverse.

\section{Finances and other concerns}

On January 31, 1766, exactly one year after the Aviso Régio ceded the property, workers completed renovations necessary to convert the Jesuit monastery at São Cristóvão into a hospital. It had space for 182 patients, employees, and slaves. Fifty-two patients and personnel that included male and female slaves from local jails moved into the hospital. All concerned must have considered this a palace compared to the shacks they had occupied since 1741. Renovation of the monastery had consumed half of the 6:412\$921 réis paid as an indemnity to the city by the Companhia dos Vinhos do Alto Douro. Count da Cunha used the other half for furnishings, to which the Administration of the Candelária contributed 1:664\$164 réis (Souza Araújo, 1946a, p. 66; Pinheiro, 1893, p. 20).

From 1766 until 1807, the hospital survived by taxation, charitable contributions including those of the Irmandade, testamentary property, and the sale of cow hides from its beef supply and a small surplus of vegetables from the hospital garden. The tax levied on the citizens of Rio for the hospital and charitable support from the Catholic Church were inconsistent. Not unlike the government, the Irmandade's efforts to collect taxes from those capable of paying proved difficult. On occasion, those whom the Irmandade appointed or subcontracted to collect the tax themselves became suspect in terms of competence, diligence, and honesty (Souza Araújo, 1946a, pp. 66-107). The latter criticism never included members of the Irmandade, only their designees.

A 1790 hospital census revealed that the facility had 69 male patients with 47empty beds and 48 female patients with eighteen beds available. ${ }^{14}$ The 117 patients undoubtedly represented no more than a third of the victims of the disease in the city of Rio. Some hid in terror and others roamed the streets. During its entire history, from 1763 to 2002, the hospital never housed more than about a third of those with the disease in the city.

Luiz Edmundo (1971, p. 302) affirmed that leprosy remained a serious endemic disease in Rio during the period of the viceroys (1763-1808). He described Rio as "a hotbed of pustules and sores"; "bands of suffering lepers roamed the streets like abandoned dogs." This state of affairs in the public health arena again demanded attention at the vice-regal level. On August 27, 1790, the Conde de Rezende, the new viceroy, directed the desembargador (senior royal magistrate) ouvidor geral do crime (superior crown magistrate of 
the district assigned to criminal matters), Dr. João Manoel Guerreiro de Amorim Pereira, to proceed with a thorough investigation into the organization, maintenance, and efficiency of the hospital (Souza Araújo, 1946a, p. 78).

Dr. Guerreiro submitted his report to the viceroy in November 1790. That report did get a reaction. The viceroy exhibited great concern for the public health hazard of so many with the disease roaming the streets and questioned the adequacy of the hospital and its resources. The viceroy instructed Dr. Guerreiro, in a final and unambiguous directive, to place all of Rio de Janeiro's remaining leprosy victims in the hospital with enough support to provide a comfort level adequate to keep them there..$^{15}$ That idealistic objective was never completely realized, in Rio or elsewhere.

During the 'time of the viceroys' hospital officials had intermittent difficulty meeting the patients' medical and surgical needs as demanded by the governing statutes. Occasionally too, a priest was not readily available at all times of the day and night, also as mandated by statute. Institutional directives obviated the reasonable expectation that the hospital could easily obtain the services of a physician and surgeon. Statute eight compelled the doctor under contract to make a minimum of two visits a week and the surgeon, an employee of the hospital, to remain in residence (Souza Araújo, 1946a, p. 68). Fulfilling the letter and even the spirit of that statute became a recurrent problem. Despite these and other administrative challenges, officials representing the hospital, the government, and the Irmandade invariably exhibited due diligence in their attempts to meet patients' physical and spiritual needs. Throughout the colonial epoch, particularly in the 'time of the viceroys', all levels of society, from commoners in Brazil to government officials there and in Portugal, exhibited an unusual level of interest and concern with leprosy and its perceived threat to public hygiene. This appears particularly so when viewed within the context of Portugal's domestic and international intrigues and circumstances in Brazil.

Events on the Iberian Peninsula in 1807 led to profound changes in the history of Brazil and the Leprosy Hospital of Rio de Janeiro. On November 29, 1807, the Portuguese court fled from Napoleon's army, and arrived at Salvador, Bahia, on January 22, 1808. After a month of enthusiastic Bahian hospitality, Prince Regent Dom João departed for Rio, where he and his entourage disembarked on March 8. On that fateful occasion Brazil changed forever.

The arrival of the Portuguese court acted as an immediate accelerator to the population growth that Rio de Janeiro had already experienced to some extent following its elevation to vice-regal capital in 1763. Although the actual number remains problematic, a multitude of courtiers and sycophants accompanied the court to the city in 1808 (Conniff et al., 1971, p. 40). ${ }^{16}$ Such an abrupt influx of 
people quickly surpassed the city's inveterately inadequate infrastructure and its equally marginal medical and public health services. Rio's demographic cataclysm, in concert with changing attitudes regarding politics and the public's health, spawned the hygienic movement there in the nineteenth century. The highly visible leprosy hospital and its unique specialty contributed to the intensification of public and political sensitivity to all health issues. As a member of Rio's hospital community and custodian of patients with a disease that had a long history of profound physical and spiritual implications, the hospital at São Cristóvão would inevitably receive intense royal attention. That attention radically altered its history.

Shortly after his arrival in Rio, the prince regent established a country home in the Quinta da Boa Vista in the São Cristóvão parish, where he spent most of his time. ${ }^{17}$ The prince and the patients became neighbors, no more than a mile apart. A mangrove swamp separated both locations from downtown Rio and required a long boat ride in the bay to get to and from the city. Sparing no expense, Dom João had a road of stone laid across the swamp, leaving São Cristóvão only four miles away from the city center. The trip took more or less half an hour by carriage. The road, known as the Caminho das Lanternas, or Road of the Lanterns, had the lavish feature of having lanterns hung about every fifty meters for use when the prince regent passed at night. He could ill afford to list courage as one of his virtues (Schlichthorst, 1943, pp. 50-1). The proximity of the beautiful hospital to the palace would later prove to be unfortunate. Also, as the population grew in São Cristóvão, so did attempts to encroach on the hospital's property. Hospital administrators and the Irmandade won several legal battles that ensued.

The intendente de polícia (the superintendent of police) visited the hospital in 1814 and made some suggestions concerning its administration. ${ }^{18}$ After passing through the bureaucratic hierarchy, these ideas led to the prince regent's authorization of seven additional statutes in $1815 .{ }^{19}$ The first, and most revealing, of the new statutes ordered the intendente do ouro da corte (who functioned as secretary of finances) to serve simultaneously in a new position designated Juiz Conservador do Hospital dos Lázaros (Judge Protector). This statute made the judge responsible for overseeing every aspect of the hospital and its mission. The fourth statute stipulated that the judge and hospital administrators visit the hospital monthly. That statute also directed the judge to be in attendance when representatives of the Irmandade made their quarterly visits to the hospital. ${ }^{20}$ Clearly, by 1815 , the leprosy hospital had the dubious distinction of having achieved an increasing intensity of official interest. 
Domestic and geopolitical events soon accelerated, leading to dramatic changes in the life and history of the hospital. Five battalions of Portuguese regular troops reached Brazil's capital in October 1817, where officials had not adequately planned for permanent billeting. One contingency of these soldiers had been assigned, again without barracks, as security for the monarch and his family. João, king since the death of his mother in 1816, and his staff looked at last with longing at the fine property occupied by his sick neighbors at São Cristóvão. Coincident with the need to house troops, concern had escalated about the proximity of the hospital to the expanding city. The decision to turn the hospital into a barrack precipitated the thorny question of what to do with the patients and staff (Souza Araújo, 1946a, pp. 161-2). The solution would not bring happiness to their ranks.

\section{The leprosy hospital on the Island of Enxadas}

After a great deal of furious interdepartmental correspondence and maneuvering, in 1817, officials of the Repartição de Marinha (Maritime Agency) rented a property on the Island of Enxadas in Guanabara Bay near the city. ${ }^{21}$ A royal mandate of October 4, 1817, evicted the patients and all related personnel from São Cristóvão and mandated their relocation on the island. ${ }^{22}$ Apparently no one wanted to leave. Under official coercion, actually a thinly veiled threat, 72 patients and the staff began to leave São Cristóvão on October 30. Only three days after the move was completed, the first patient death occurred on November 5. Of 21 deaths in the hospital in 1817, a third of them occurred on the Island of Enxadas between November 5 and December $28 .{ }^{23}$ The move to the Island of Enxadas had taken a grim toll. Frei Vicente Guimarães recorded that the first patient who died on Enxadas was returned to the chapel at São Cristóvão for burial (Souza Araújo, 1946a, p. 165). Those who survived would not return there for another decade.

The Island of Enxadas location proved disastrous. All food and water had to be transported and that was totally unreliable. ${ }^{24}$ The Island did not contain enough soil to grow food or to bury the dead, which occurred at an alarming rate. Housing was woefully inadequate. ${ }^{25}$ Hospital board members immediately began a frantic search for another location. Change would not come until five years later, in 1822.

Finally, by letter, on September 12, 1822, Prince Regent Dom Pedro acknowledged 'for the second time' the unacceptable state of the hospital on the Island of Enxadas and reminded the hospital's administrative board of the planned move to the Island of Bom Jesus and into the Monastery of São Francisco. He assured board members that the island had all necessary amenities. ${ }^{26}$ The timing of 
this document concerning the hospital has some significance in the face of far more compelling issues, coming only five days after Brazil's declaration of independence. It would not be until January 23, 1823, that emperor Dom Pedro I actually signed the resolution ordering the relocation of the hospital to the monastery on the Island of Bom Jesus (Azevedo, 1969, p. 207). The hapless patients then followed the hospital into the most wretched chapter of its history.

\section{The leprosy hospital on the Island of Bom Jesus}

The move took place on February 3, 1823. Difficulties suffered on Enxadas intensified on the Island of Bom Jesus. The staff soon lodged complaints and the patients exercised a by-then institutionalized tradition of communicating their grievances to the highest authorities (Souza Araújo, 1946a, p. 269). As an example of a serious complaint, during the reign of Dom Pedro I from 1822 to 1831, the hospital never had a physician, only a marginally qualified and less than compassionate surgeon (ANRJ, 1831-1833; Souza Araújo, 1946a, p. 276).

Escape from the hospital on the island became a symptom of discontent, and that attracted public attention. Patients endured crowding, an inadequate diet, a devastating disease, and little hope. In 1829, the hospital's judge (conservador) protested to Emperor Pedro I that the hospital had only two infirmaries in which to crowd patients of both sexes, from different races, and of widely ranging ages and degrees of disease. Patients and staff preferred the past miserable existence on the Island of Enxadas to their tenuous present on Bom Jesus. ${ }^{27}$ Once again, politics intervened, this time favorably.

The fate of Rio's leprosy hospital has always had some inextricable links with political events locally and nationally. The next turn in its history and return to São Cristóvão came after Emperor Dom Pedro I, who had tuberculosis, first succumbed to various attacks on his political health. He renounced the throne in 1831, in favor of his son Dom Pedro de Alcântara, then only five years and five months old. The regency period that immediately followed would prove advantageous to the patients on the Island of Bom Jesus.

Brazil's three temporary regents inherited major national problems in addition to the leprosy hospital on the island with its deplorable public image. On May 28, 1831, the administrative board of the hospital petitioned the regency government to allow it to return to São Cristóvão. ${ }^{28}$ The regency passed this to the Municipal Council, which approved. ${ }^{29}$ 


\section{Return to São Cristóvão}

On August 25, 1832, the General Assembly made two important resolutions concerning the leprosy hospital, which the regents then decreed. The first changed and renamed the traditional involuntary 'contribution' for the lepers to a "voluntary contribution for the benefit of the lepers" and authorized the necessary government expenditures to support the leprosy hospital. The second ordered the move of the leprosy hospital to its original location in the old Jesuit monastery at São Cristóvão, with the public treasury paying for all necessary repairs and renovations. On October 24, 1832, a law passed granting the leprosy hospital 8:900\$000 for renovations and a subvention of $500 \$ 000$ a month (Souza Araújo, 1946a, p. 296). The patients and staff returned to their old home in São Cristóvão on February 18, 1833, despite some protests in the parish. ${ }^{30}$ The leprosy hospital of Rio de Janeiro thus emerged from its darkest years on the Island of Enxadas and the Island of Bom Jesus.

With a few notable disappointments, the leprosy hospital had a more mellifluous history after Dom Pedro II became emperor in 1840. The hospital profited indirectly from his attention to its leadership and governance and his infinite curiosity. As an example of his sensitivity, Dom Pedro II took offense at the inscription, taken from Dante's Divine Comedy, which appeared on the wrought iron gate at the hospital's main entrance. It stated, "Leave all hope, ye that enter." He had it changed to "aqui renasce a esperança" or "here hope is reborn" (Thielen et al., 1995).

With no effective treatment, hope was difficult to sustain. During the nineteenth century desperate attempts to treat the disease sometimes bordered on the bizarre. The general session of the Imperial Academy of Medicine in Rio on August 26, 1841, chaired by Dr. Francisco de Paula Cândido (1842, p. 497), focused on the issue of the causes and treatment of leprosy, including snake venom. In a thesis for the faculty of medicine in 1845, José Martins (1845, pp. 29-30) included a reminder that numerous authors recommended the venom of the rattlesnake, coral snake, or jararacucu, also called the jararaca. Live snakes, not the doctor, injected the patient. Records exist of one patient from the hospital who died a gruesome death within 24 hours after volunteering for that 'heroic' treatment. ${ }^{31}$ The use of snakebite in treating patients with advanced disease did not end quickly enough and was lauded as late as 1868 (Freitas, 1856; Lopes, 1868, pp. 20-1).

Most can appreciate the frustration of trying to treat leprosy before the sulfones began to be used effectively in 1941. Yet patients of the hospital at São Cristóvão traditionally received the finest care available at the time and the medical staff stayed abreast of contemporary international ideas and innovations. Dr. José Jerônimo de Azevedo 
Lima, the hospital's physician, asserted in his 1880 annual report that without any doubt, patients there received excellent care in one of the city's premier landmark facilities. His thoughtful commentary lamented that the treatment and fate of a patient in the leprosy hospital of Rio de Janeiro had changed little. He also related that patients continued to escape from the hospital, not because of disingenuous treatment or malevolent care, but out of despair for the futility of their situation. Patients seemed to prefer to stay with their families or simply remain free to pursue their own destinies (AMINSC, 1880).

Efforts to make the hospital a more hospitable environment never abated, nevertheless. Provedor Luiz Augusto de Magalhães established a school for hospitalized patients in 1882. That did not succeed because the patients usually had advanced disease and simply could not attend classes (Pinheiro, 1893, p. 80). An impressive library was opened in 1883. All concerned stressed that it was established not simply as an ornamental luxury but to benefit the patients (Pinheiro, 1893, p. 81).

The annual report of 1887 mentioned that for several months Dr. Adolfo Lutz had visited the hospital to do research in collaboration with Dr. Azevedo Lima (AMINSC, 1887) ${ }^{32}$ Dr. Lutz later became one of the giants of medical history in Brazil and one could argue that modern Brazilian medical science started during that time and in that hospital. Dr. Lutz's other contribution to modern Brazil was a remarkable daughter, Bertha, who in the 1930s led Brazil's women's suffrage movement. Unfortunately, Dr. Lutz defended his erroneous belief in the mosquito transmission of leprosy until his death on November 5, 1940, at the age of 84 (Souza Araújo, 1946b, estampa 2).

The annual report published in 1888 related that, at the suggestion of the emperor, Dom Pedro II, the administration had established a special room near the entrance to the hospital. It was referred to as the Sala do Banco (Room of Benches), for free physician consultations between patients, their families, and concerned citizens (AMINSC, 1888). Known as the room of hope, it remains intact today with its beautiful stained glass window etched with the message "aqui renasce a esperança." This room commands the stature of a monument within the greater "monument to Lazarus."

The 1889 Relatório of the Irmandade affirmed that the hospital continued to have a strong and effective administration. While in its last year as the Imperial Leprosy Hospital of Rio de Janeiro, social and political tension in the city and country did not appear to have detracted from its excellence as a medical institution, or impaired its administrative process. With the quiet end of Brazil as an empire on November 15, 1889, and the departure of the elderly and ailing Dom Pedro II, the hospital lost perhaps its most influential single 
friend, but it did not lose the quiet determination of the Irmandade to continue to fulfill its covenant of 1763 .

Unlike the country, the hospital began the first decade in republican Brazil with financial stability and ambition on the part of its leaders to maintain a modern hospital that was scientifically current. A worldclass bacteriology laboratory officially opened in the hospital in 1894. Improvements also continued in other areas of patient care and comfort.

Unfortunately, the Irmandade faced another serious threat to its beloved hospital. Financial volatility accompanied the beginning of Brazil's republican era and its leaders began to look, with some desperation, at any potential source of revenue. They did not fail to notice that striking property, the hospital in São Cristóvão, which was already a national patrimony. Ironically, the head of Brazil's provisional government, General Manuel Deodoro da Fonseca, made the first significant donation to the hospital in its republican history (AMINSC, 1890).

A major threat to the institution occurred in the form of article 23 of law $\mathrm{n}^{\circ} 490$ of December 16, 1897, which redefined the nation's property for the use of its citizens at the discretion of its leaders. A distinguished member of the Irmandade, Dr. Aristides Milton, succeeded in passing an amendment to exempt the leprosy hospital and to make the hospital entity its owner (AMINSC, 1898). On December 19, 1898, the provedor managed to have documents executed by the Fazenda Nacional (National Treasury) that transferred the ownership of the hospital to the Irmandade (Souza Araújo, 1956, p. 286). The provedor's methods and most of the facts surrounding that remarkable accomplishment remain obscure. We do know that, then as now, the Irmandade is composed of many of Rio's most influential people. Dr. Oswaldo Cruz ordered a report on public health services in Brazil with an emphasis on Rio from 1808 to 1907. That report confirmed the Irmandade as the owner of the hospital (Barbosa et al., 1909, p. 243).

Despite the political and financial uncertainties during the first decade of Brazil's republican experiment, the hospital continued to be one of Rio's finest. The quality of its medical staff also improved in the last decade of the nineteenth century. With the hiring of Dr. Wolff Havelburg, highly trained in bacteriology and pathology; Dr. João Pizarro Gabizo, a professor of dermatology; and Dr. Graça Couto, an ophthalmologist, hospital administrators exhibited a commitment to acquiring the most highly qualified physicians available. That commitment also heralded the beginning of specialization in Brazilian medicine.

The hospital's high profile began to change soon after the dawn of the twentieth century. The newly founded Federal Serum Therapy Institute of Manguinhos hired Dr. Oswaldo Cruz in 1900 and forever 
changed the scientific environment and trajectory of the public's health in Brazil. That event also shifted a great deal of enthusiasm for basic and clinical research away from the leprosy hospital, with its more limited sphere of interests (Stephan, 1976, pp. 6, 72-3).

With the hospital still receiving some public support, in 1916, government officials once again focused on the institution and quite emphatically suggested that the Irmandade move the patients from São Cristóvão to a new location, appropriately remote from the city. Dr. Emilio Ribas, a noted expert, visited the hospital, declared it a model of hygiene, and credited its administration with the ability to correct any public concerns (AMINSC, 1916). The hospital survived yet another threat.

Up until 1920, the needs of victims of leprosy and other public health and hygiene issues had remained largely in the realm of private initiative. With Dr. Carlos Chagas' inspiration, health legislation in 1920 restructured the National Department of Public Health (Prata, 1990, p. 1). With that new impetus, between 1920 and 1934, Brazil's federal government opened new and expanded several existing facilities for the treatment of leprosy. One of the most notable already in operation near Rio was Curupaiti, which began to admit leprosy patients in 1928, some of whom were transferred there from the leprosy hospital of Rio. Curupaiti had a capacity five times that of the São Cristóvão facility and also had advanced general hospital facilities to handle other medical disorders.

With the so-called Revolution of 1930, Brazil entered the era of Getúlio Vargas and the Leprosy Hospital of Rio de Janeiro began to lose even more of its prestige as larger institutions replaced its previously unique position within Rio's public health system. Few realized it at the time, but by the 1940s the beginning of the end had come for the hospital. The Irmandade changed the hospital's name to Hospital Frei Antônio in 1940, in honor of the person most singularly responsible for its founding. Those fighting the battle against the continued use of the word 'leprosy' and its associated stigma also approved of the new name (AMINSC, 1940). With the advent of antibiotic treatment in 1941, followed by multidrug therapy today, management of leprosy patients changed forever. Reversing the associated stigma has been far more difficult.

Today, the beautiful Hospital Frei Antônio continues to care for five patients who have no other home. Its history will soon end as the last of those five elderly patients return to the dust from whence they came. But, the legacy of this magnificent and benevolent institution will live on, unseen, but intrinsic to the society that surrounds it. 


\section{NOTES}

1 The population of Rio de Janeiro increased from 12,000 in 1706 to 24,397 in 1749 . For the former numbers see Leite (1946, p. 15). For the latter number see Southey (1970, p. 813). Southey's first book was published in 1822. Other authors report that at that time Rio de Janeiro had four hundred victims of leprosy roaming the streets. See also Souza Araújo (1946a, pp. 9-15).

${ }^{2}$ For a discussion of these complex relationships see Russell-Wood (1992, chapter 3).

3 Arquivo Nacional do Rio de Janeiro (henceforth ANRJ), vol. 1. Letter of May 23, 1740, from the Municipal Council of Rio de Janeiro to the Crown.

${ }^{4}$ Carta régia of February 3, 1741, to Gomes Freire de Andrade (Souza Araújo, 1946a, p. 33; ANRJ, 1740-1822).

5 In a royal judicial writ of September 4, 1758, bishop Dom Antônio do Desterro, brigadeiro José Fernandes Pinto de Alpoim, and Minister of the High Court of Appeals, João Alberto Castelo Branco, were named as a triumvirate to govern in the event of the death of governor and Captain General Gomes Freire de Andrade (Souza Araújo, 1946a, p. 32).

${ }^{6}$ Frei Antônio, whose secular name was Antônio Reimão Malheiros, held a Doctor of Theology degree from the University of Coimbra. F. B. Marques Pinheiro refers to him as the "master of bishops." He had been named bishop of Rio de Janeiro on January 18, 1747, and was confirmed on February 7, 1747 (Varnhagen, 1959, vol. 4, p. 91).

7 Viceroy Count da Cunha. The Count, Antônio Álvarez da Cunha, a professor of canon law at the University of Coimbra, joined the High Court of Bahia in 1741 (Schwartz, 1973, p. 296).

${ }^{8}$ Letter from viceroy Count da Cunha to Francisco Xavier de Mendoça Furtado (ANRJ, Dec. 19, 1763).

${ }^{9}$ Maxwell (1995, p. 62) laments that "the title of the company is almost invariably mistranslated (indeed it is very often mistranscribed even in Portuguese), transforming vinhas (vineyards) into vinhos (wine), thus misrepresenting entirely the major objective of the company. Pombal had given that company, made up of the most influential owners of the richest "vineyards" of the upper Douro River of Portugal, monopoly rights to sell their wines in Brazil.

10 Letter from viceroy Count da Cunha to Francisco Xavier de Mendoça Furtado. This letter, copied by Pedro Henrique da Cunha and placed in the archives at an unknown time, has at least one obvious error in referring to the royal resolution of August 27, 1765, and not 1760 or 1761 (ANRJ, Dec. 19, 1763).

11 The National Archives of Rio de Janeiro has a copy of two sections of Francisco Xavier de Mendoça Furtado's reply to Count da Cunha, indicating that the Irmandade had the original. Pedro Henrique da Cunha signed that copy as certification of its accuracy. Varnhagen (1959, vol. 5, p. 87), in chapter notes, refers to Pedro Henriques da Cunha regarding an edict of the viceroy on February 18, 1804. "Vem por cópia na Noticia curiosa e proveitosa a beneficio da Real Fezenda sobre o princípio, estado passado, e presente da fazenda de Santa Cruz, que foi dos denominados jesuitas, e hoje incorporada na real Coroa, por Pedro Henrique da Cunha, na Biblioteca Nacional, seção de Manuscritos, cód. I-7, 3, 21, fls.170 v./172v." This note then continues with the full text of the decree. Henrique da Cunha also signed other documents from the ANRJ that appear in this study.

12 Certified copy of Francisco Xavier de Mendoça Furtado's reply to Count da Cunha dated January 31, 1765 (ANRJ, 1740-1822).

13 Copies of the 22 statutes that governed the leprosy hospital are found in ANRJ (Mar. 13, 1766).

${ }^{14}$ Hospital census dated 1790 and unsigned. See ANRJ (1740-1822).

15 Report of November 13, 1790, from desembargador ouvidor geral do crime João Manoel Guerreiro de Amorim Pereira to the viceroy is found in ANRJ (1740-1822).

16 These figures vary, but around ten thousand seems most reasonable. See also Skidmore (1999, p. 35).

17 Dom João discovered in 1806 that his wife Dona Carlota planned to depose him in a palace coup. As a result of that and other blatant indiscretions by Carlota, the two lived separately. The princess and her daughters occupied first the urban palace in Rio and later a house in the seaside suburb of Botafogo. The prince regent, his two sons, and a nephew resided in the house at São Cristóvão (Costa, 1950, p. 26).

18 Letter of May 1, 1814, from Paulo Fernandes Vianna to the marquês de Aguiar in ANRJ (1740-1822).

19 Letter of March 29, 1815, from the prince regent to the marquês de Aguiar (ANRJ, 1740-1822). See also Souza Araújo (1946a, pp. 153-6).

${ }^{20}$ Letter of March 29, 1815, in ANRJ (1740-1822).

21 Letter of October 2, 1817, from João Manoel da Silva to Thomaz Antônio Villanova Portugal in ANRJ (1740-1822). 


\footnotetext{
${ }^{22}$ Royal dictum of October 4, 1817, signed by Sebastião Luiz Tinoco da Silva evicting the patients and personnel of the leprosy hospital at São Cristóvão and ordering them to the Ilha das Enxadas found in ANRJ (1740-1822).

23 Hospital census for 1817 dated April 4, 1818, in ANRJ (1740-1822).

24 Letter from the leprosy hospital administrative board to desembargador Lucas Antônio Monteiro de Barros in December [?], 1817 found at the Biblioteca Nacional (henceforth BN), II-34, 28, 8. See also, Souza Araújo (1946a, p. 165).

25 Letter of December [?], 1817, from the leprosy hospital board to desembargador Lucas Antônio Monteiros de Barros found at BN, II-34, 28, 8 .

${ }^{26}$ Letter of September 12, 1822, from Dom Pedro to the administrative board of the leprosy hospital in the ANRJ (17401822).

${ }^{27}$ Representação do juiz conservador e administradores do Real Hospital dos Lázaros, 1829 (BN II-30, 28, 25).

28 Petition of May 28, 1831, from the administrative board of the leprosy hospital to the regency, requesting the return of the leprosy hospital to the monastery at São Cristóvão ANRJ (1831-1833).

${ }^{29}$ Letter of the Municipal Council (Câmara Municipal) of Rio de Janeiro, of June 30, 1831, approving the return of the leprosy hospital from the Ilha do Bom Jesus Franciscano monastery to the old Jesuit facility at São Cristóvão (ANRJ, 1831-1833).

30 Petition of February 22, 1833, from the people of the district of São Cristóvão to the Regency, opposing the assembly resolution of August 25, 1832 (ANRJ, 1831-1833).

31 Cross-referencing suggests that the patient who died from the snakebite in 1839 was the same one Reverend Daniel Kidder described (Kidder, 1845, pp. 81-2; Martins, 1845, pp. 29-30).

32 Adolfo Lutz married an English nurse, Amy Fowler, who had worked in the leprosy colony in Hawaii. In 1894 in São Paulo they had a daughter, Bertha Lutz, who became a leader for women's rights and suffrage in Brazil (Hahner, 1990, pp. 134-8).
}

\section{BIBLIOGRAPHIC REFERENCES}

Alden, Dauril

AMINSC

ANRJ

Arquivo Morto da Irmandade de Nossa Senhora da Candelária

Arquivo Nacional do Rio de Janeiro

Azevedo, Manuel

Duarte Moreira de 1969

Barbosa, Plácido and Rezende, Cássio

Barbosa de 1909

Biblioteca Nacional 1817, 1829

$\mathrm{BN}$

Cândido, Francisco de Paula

Jan. 1842
'Manoel Luís Vieira: an entrepreneur in Rio de Janeiro during Brazil's eighteenth century agricultural renaissance'. Hispanic American Historical Review, 39, pp. 521-37.

see Arquivo Morto da Irmandade de Nossa Senhora da Candelária.

see Arquivo Nacional do Rio de Janeiro.

Relatórios. 1880, 1887-1890, 1898, 1916, 1940.

Fundo Hospital dos Lázaros - código 039. Caixa 1.639, vol. 1; vol. 2, 1740-1822, 1831-1833.

O Rio de Janeiro, sua história, monumentos, homens, notáveis usos e curiosidades. Rio de Janeiro, Brasiliana, vol. 1.

Os serviços de saúde pública no Brasil: especialmente na cidade do Rio de Janeiro de 1808 a 1907. Rio de Janeiro, Imprensa Nacional, vol. 1.

\section{Assorted documents.}

see Biblioteca Nacional.

'Sessão geral em 26 de agosto de 1841: Academia Imperial de Medicina'. Revista Médica Brasileira, 1:9, pp. 494-9. 


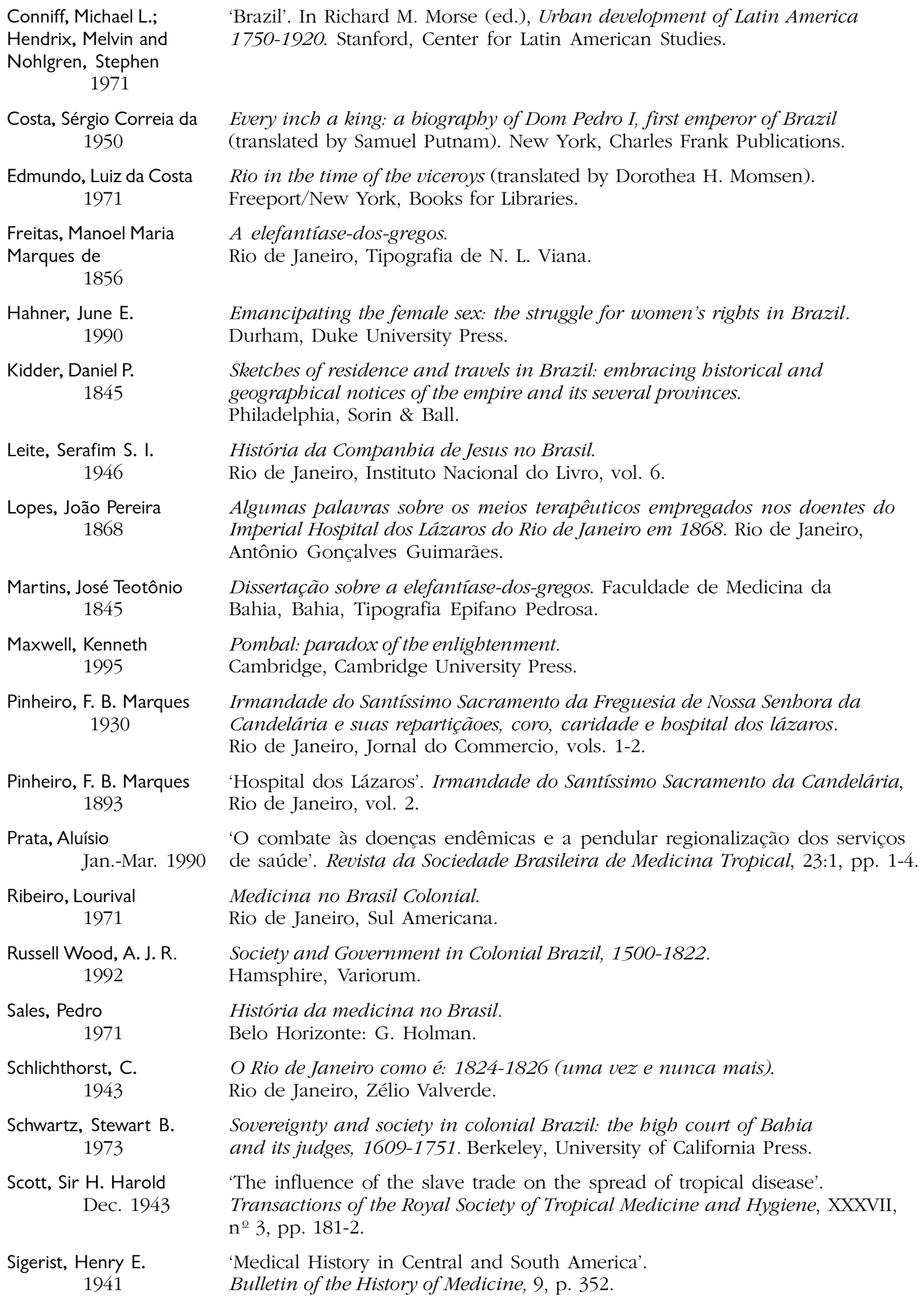

Conniff, Michael L.; Hendrix, Melvin and 1971

rgio Correia da

Luiz da Costa

Manoel Maria

1856

aniel $\mathrm{P}$

afim S. I.

ão Pereira

1868

osé Teotônio

Kenneth

F. B. Marques 1930 1893

Jan.-Mar. 1990

ourival

od, A. J. R.

dro

orst, C.

Stewart B.

H. Harold

Dec. 1943

1941

'Brazil'. In Richard M. Morse (ed.), Urban development of Latin America 1750-1920. Stanford, Center for Latin American Studies.

Every inch a king: a biography of Dom Pedro I, first emperor of Brazil (translated by Samuel Putnam). New York, Charles Frank Publications. Freeport/New York, Books for Libraries.

A elefantiase-dos-gregos.

Emancipating the female sex: the struggle for women's rights in Brazil. geographical notices of the empire and its several provinces. Porin \& Ball.

História da Companhia de Jesus no Brasil.

Algumas palavras sobre os meios terapêuticos empregados nos doentes do Imperial Hospital dos Lázaros do Rio de Janeiro em 1868. Rio de Janeiro, Antônio Gonçalves Guimarães. Bahia, Bahia, Tipografia Epifano Pedrosa.

Irmandade do Santíssimo Sacramento da Freguesia de Nossa Senhora da Candelária e suas repartiçãoes, coro, caridade e hospital dos lázaros. Rio de Janeiro, Jornal do Commercio, vols. 1-2. Rio de Janeiro, vol. 2

'O combate às doenças endêmicas e a pendular regionalização dos serviços

Medicina no Brasil Colonial.

Rio de Janeiro, Sul Americana.

Society and Government in Colonial Brazil, 1500-1822.

O Rio de Janeiro como é: 1824-1826 (uma vez e nunca mais)

Sovereignty and society in colonial Brazil: the high court of Babia Cerkeley, University of California Press. $\mathrm{n}^{\circ} 3$, pp. 181-2.

Bulletin of the History of Medicine, 9, p. 352. 
THOMAS HUNTER SMITH III

Skidmore, Thomas E. 1999

Southey, Robert 1970

Souza Araújo, Heráclides César de 1956

Souza Araújo, Heráclides César de $1946 a$

Souza Araújo,

Heráclides César de $1946 b$

Stephan, Nancy 1976

Terra, Fernando 1919

Thielen, Eduardo and Coimbra, Luiz Octavio (prod. and dir.)

$$
1995
$$

Varnhagem, Francisco Adolpho de 1959
Brazil: five centuries of change. New York, Oxford University Press.

History of Brazil: part the third. New York, Burt Franklin.

História da lepra no Brasil: período republicano (1890-1952).

Rio de Janeiro, Imprensa Nacional, vol. 3.

História da lepra no Brasil: períodos colonial e monárquico (1500-1889). Rio de Janeiro, Imprensa Nacional, vol. 1.

História da lepra no Brasil: periodo republicano — álbum das organizações antileprosas (1889-1946). Rio de Janeiro, Imprensa Nacional, vol. 2.

Beginnings of brazilian science: Oswaldo Cruz, medical research and policy, 1890-1920. New York, Science History Publications.

'Lepra no Rio de Janeiro: seu aparecimento, freqüência e formas'. O Brazil-Medico, 33(6), pp. 33-44.

Iarerê: hanseniase e mentalidades no Rio de Janeiro. Casa de Oswaldo Cruz, videocassette, 52min.

História geral do Brasil.

São Paulo, Melhoramentos, 5 vol. 